\title{
Chickenpox Vaccination: Knowledge and Attitude of Child-Bearing Women of Abraka, Delta State, Nigeria
}

\section{${ }^{1}$ EDJE, KE; ${ }^{2}$ TOLOYAI, PY; ${ }^{2}$ MORDI, JC; ${ }^{3}$ DAUBRY, TME; ${ }^{1 *}$ MOKE, EG; ${ }^{1}$ OMOGBIYA, AI; ${ }^{1}$ SAMSON, EE}

\author{
${ }^{1}$ Department of Pharmacology and Therapeutics, Delta State University, Abraka, Nigeria. \\ ${ }^{2}$ Department of Medical Biochemistry, Delta State University, Abraka, Delta State, Nigeria. \\ ${ }^{3}$ Department of Physiology, Delta State University, Abraka, Delta State, Nigeria. \\ *Corresponding author.Email hiligoodies@gmail.com; Tel: +234-7061040692
}

\begin{abstract}
Chickenpox is a common childhood disease which is highly contagious. The World Health Organization (WHO) recommends that in countries where chickenpox is an important public health burden, chickenpox vaccination should be introduced into their routine immunization programs. This present study is to ascertain the level of knowledge and attitude towards chickenpox infection and its vaccination among child-bearing women in Abraka, Delta State, Nigeria. A cross-sectional descriptive study design was adopted to assess the knowledge and attitude towards chickenpox vaccination among 140 randomly selected child-bearing mothers residing in Abraka community. Of the 140 respondents, a greater number was within $30-40$ years of age (61.4\%). Most of the respondents (95.7\%) had heard about chickenpox and $77.1 \%$ stated correctly its mode of transmitted. Majority were well aware of the signs and symptoms of the infection which included itching rashes $(85.7 \%)$, blisters and red spots $(66.4 \%)$, and fever $(61.4 \%)$. Despite the fact that most of the respondents $(72.9 \%)$ knew about chickenpox vaccination, only very few $(19.3 \%)$ claimed to know the vaccine used, with less than half of the respondents $(44.3 \%)$ correctly indicating two doses as the complete dosing for chickenpox vaccination. A greater proportion (91.4\%) of the women had vaccinated their children against chickenpox, and believed that it was effective $(82.1 \%)$. A high level of knowledge and positive attitude towards chickenpox vaccination among child-bearing women was evident in this study, however, it is paramount to encourage pregnant women and mothers attending antenatal care to immunize their children against vaccine-preventable diseases (VPDs).
\end{abstract}

DOI: https://dx.doi.org/10.4314/jasem.v24i6.17

Copyright: Copyright $(C 2020$ Edje et al. This is an open access article distributed under the Creative Commons Attribution License (CCL), which permits unrestricted use, distribution, and reproduction in any medium, provided the original work is properly cited.

Dates: Received: 29 April 2020; Revised: 30 May 2020; Accepted: 19 June 2020

Keywords: Vaccination, chickenpox, vaccine-preventable diseases, knowledge, Abraka.

Chickenpox is a common childhood disease, which usually confers lifetime immunity. Varicella (also known as chickenpox) and herpes zoster (HZ, also known as shingles) are caused by varicella-zoster virus (VZV), a highly contagious herpes virus (WHO, 2014; Wutzler et al., 2017). Varicella-zoster virus is present globally and, where there is no varicella vaccination programme, majority of people become infected by mid-adulthood (WHO, 2014). The mode of transmission of the virus is from person to person via direct contact with the varicella or $\mathrm{HZ}$ rash, inhalation of aerosolized droplets from respiratory tract secretions of patients with varicella, or in rare cases from the inhalation of aerosolized droplets from vesicular fluid of skin lesions of patients with varicella or disseminated HZ (WHO, 2014). The virus gains access to the body of the host through the upper respiratory tract or the conjunctiva. Gershon et al., (2013) reported that the virus remains dormant in the sensory nerve ganglia after primary infection, and it can reactivate later in life. Chickenpox causes a relatively lower global burden of disease-specific mortality than other major infectious diseases such as measles, pertussis, rotavirus, or invasive pneumococcal disease (Lozano et al., 2012). Chickenpox infection typically confers immunity for life, however, in rare cases of second attacks of varicella have been documented (WHO, 2014). World Health Organization (WHO) recommends that in countries where chickenpox is an important public health burden, chickenpox vaccination should be introduced into their routine immunization programs (WHO, 2014). Recommended dosing for varicella vaccination may include one or two doses, separated by a dosing interval. A first dose at 12-18 months followed, if adopted, by a second dose at $4-6$ years of age is the most common schedule. Otherwise, the second dose can be given to children at an earlier age (below 4 years) provided it is given at least 3 months after the first dose (Marin et al., 2007; Bonanni et al., 
2013; Wutzler et al., 2017). The two commonly used varicella vaccines include Varilrix ${ }^{\circledR}$ (GSK, Belgium) or Varivax ${ }^{\circledR}$ (Merck, USA) which is administered as a monovalent vaccine, and Priorix ${ }^{\circledR}$ (GSK, Belgium) or ProQuad ${ }^{\circledR}$ (Merck, USA) administered as a quadrivalent vaccine in combined with the measles, mumps, and rubella vaccine (MMRV) (CDC, 2016; Wutzler et al., 2017). The use of chickenpox(varicella) vaccines (Varivax and Proquad) has been shown to be safe and efficacious in reducing the incidence and associated morbidity (Kreth et al., 2008; Tafuri et al., 2010; Kurugol et al., 2011; Ma et al., 2015). Varicella vaccination has been shown to be associated with a significant decrease in varicella-related hospitalization rates (Streng et al., 2013; Siedler and Dettmann, 2014; Leung and Harpaz, 2016). Previous studies have indicated that mothers play an important and critical role in protecting their children from acquiring and transmitting vaccine-preventable diseases (VPDs) through increasing the vaccination coverage (Coniglio et al., 2011).

The specific mechanism is that the knowledge and perception of the benefit of vaccination can influence a mother's choice to immunize her children. Furthermore, some studies demonstrated that pregnant women's knowledge and attitude regarding vaccination could have an early and positive influence on the practice of getting vaccinated (Trim et al., 2012; Hu et al., 2017; D'Alessandro et al., 2018). To the best of our knowledge, not much is known about the knowledge and attitude of child-bearing women towards chickenpox vaccination in Abraka, Delta State, Nigeria. Thus, this present study is to ascertain the level of knowledge and attitude towards chickenpox infection and its vaccination among childbearing women in Abraka, Delta State, Nigeria.

\section{MATERIALS AND METHODS}

A cross-sectional descriptive study design was used to assess the knowledge and attitude towards chickenpox vaccination among child-bearing mothers residing in Abraka community, Ethiope East Local Government Area, Delta State, Nigeria. A total of 140 child-bearing women were randomly recruited for this study between February and March 2019. Ethical approval was obtained from the ethical committee of the Faculty of Basic Medical Sciences, Delta State University, Abraka, Nigeria. A well-structured questionnaire was used to collect data for the study from participants who gave informed oral consent. Information collected comprised the sociodemographic data, knowledge on immunization, and attitude toward childhood immunization. Data was presented as percentage using descriptive statistics.

\section{RESULTS AND DISCUSSION}

Table 1 shows the socio-demographic data of the respondents. Of the 140 respondents, a greater number was within $30-40$ years of age $(61.4 \%)$. About twothird $(65.7 \%)$ were married, while more than half $(54.3 \%)$ the respondents have had post-primary education. Most of the respondents $(60 \%)$ were either into business or self-employed, whereas $12.9 \%$ indicated they were basically idle, not doing anything. A larger proportion $(87.8 \%)$ of the respondents had at least 3 children.

Table 1: Socio-demographic characteristics

\begin{tabular}{lll}
\hline Variable & $\begin{array}{l}\text { Frequency } \\
(\boldsymbol{n}=\mathbf{1 4 0})\end{array}$ & $\begin{array}{l}\text { Percentage } \\
(\mathbf{\%})\end{array}$ \\
\hline Age & & \\
$20-30$ & 20 & 14.3 \\
$31-40$ & 86 & 61.4 \\
$>40$ & 34 & 24.3 \\
Marital Status & & \\
Single & 26 & 18.6 \\
Married & 92 & 65.7 \\
Divorced & 10 & 7.1 \\
Widowed & 12 & 8.6 \\
Educational Status & & \\
Informal & 30 & 21.4 \\
Primary & 34 & 24.3 \\
Secondary & 56 & 40.0 \\
Tertiary & 20 & 14.3 \\
Occupation & & \\
& 24 & 17.1 \\
Business/Self-employed & 84 & 60.0 \\
ant & 14 & 10.0 \\
& 18 & 12.9 \\
Number of Children & & 3.6 \\
& 5 & 8.6 \\
2 & 12 & 32.1 \\
& 45 & 55.7 \\
\hline
\end{tabular}

An immense number of the respondents had heard about chickenpox (95.7\%). Most (77.1\%) stated correctly that chickenpox was transmitted by direct contact and/or through inhalation of aerosolized droplets. Majority were well aware of the signs and symptoms of the infection which included itching rashes $(85.7 \%)$, blisters and red spots $(66.4 \%)$, and fever $(61.4 \%)$. Despite the fact that most of the respondents $(72.9 \%)$ knew about chickenpox vaccination, only very few (19.3\%) claimed to know the vaccine administered to their children, with less than half of the respondents $(44.3 \%)$ correctly indicating two doses as the complete dosing for chickenpox vaccination (Table 2). The results concerning attitude indicated that a greater proportion (91.4\%) of the women had vaccinated their children against chickenpox, and believed that it was effective $(82.1 \%)$ (Table 2). This study helps to evaluate the level of knowledge and attitude of child-bearing women towards chickenpox vaccination. The result of the present study reflected that the child-bearing 
women of the Abraka community of Delta State, Nigeria, have a good knowledge about chickenpox infection and a positive attitude towards its vaccination.

\begin{tabular}{|c|c|c|}
\hline Category/Variable & $\begin{array}{l}\text { Frequency } \\
(n=140)\end{array}$ & $\begin{array}{l}\text { Percentage } \\
(\%)\end{array}$ \\
\hline \multicolumn{3}{|l|}{ Knowledge } \\
\hline \multicolumn{3}{|l|}{ Have you ever heard of chickenpox? } \\
\hline Yes & 134 & 95.7 \\
\hline No & 6 & 4.3 \\
\hline \multicolumn{3}{|l|}{ How can it be transmitted? } \\
\hline By contaminated water and food & 4 & 2.9 \\
\hline By direct contact and/or inhalation of aerosolized droplets & 108 & 77.1 \\
\hline By injection syringes & 28 & 20.0 \\
\hline \multicolumn{3}{|l|}{ Signs and symptoms of chickenpox infection* } \\
\hline Itching rashes & 120 & 85.7 \\
\hline Blisters and red spots & 93 & 66.4 \\
\hline Fever & 86 & 61.4 \\
\hline \multicolumn{3}{|l|}{ Have you heard of chickenpox vaccination? } \\
\hline Yes & 102 & 72.9 \\
\hline No & 38 & 27.1 \\
\hline \multicolumn{3}{|l|}{ Do you know of any chickenpox vaccine? } \\
\hline Yes & 27 & 19.3 \\
\hline No & 113 & 80.7 \\
\hline \multicolumn{3}{|l|}{$\begin{array}{l}\text { How many doses is required for the completion of } \\
\text { chickenpox vaccine? }\end{array}$} \\
\hline One dose & 53 & 37.9 \\
\hline Two doses & 62 & 44.3 \\
\hline Three doses & 25 & 17.9 \\
\hline \multicolumn{3}{|l|}{ Attitude } \\
\hline \multicolumn{3}{|l|}{$\begin{array}{l}\text { Have your child/children been vaccinated against } \\
\text { chickenpox? }\end{array}$} \\
\hline Yes & 128 & 91.4 \\
\hline No & 16 & 8.6 \\
\hline \multicolumn{3}{|l|}{ Do you think chickenpox vaccination is efficacious? } \\
\hline Yes & 115 & 82.1 \\
\hline No & 25 & 17.9 \\
\hline
\end{tabular}

Although, there was little or average knowledge about the type of vaccine administered and its dosing regimen. Knowledge relating to chickenpox and its vaccine in this study revealed that the women have heard about chickenpox infection and they correctly mentioned the mode of transmission of the infection as well as the accompanying signs and symptoms. Even though they had also heard of chickenpox vaccination, they did not know which type of vaccine was used or administered to their children and also had less knowledge about the doses for a complete vaccination process. This raises concern for the need to properly educate on chickenpox vaccination for mothers who enroll for immunization of their children at health facilities. Omotara et al., (2012), while assessing the knowledge, attitude and practice of stakeholders towards immunization in Borno State, Nigeria, reported a high level of awareness and acceptability of immunization as parents not only accepted the programme but also presented their children for immunization. Similar study by Njidda et al., (2017) showed that parents in Maiduguri, Borno State, Nigeria, were well knowledgeable about the benefits of child immunization. In this study, a positive attitude towards chickenpox vaccination was observed among the mothers as a large majority (91.4\%) accepted the vaccination as they reportedly presented their children for chickenpox vaccination. They also saw it as effective. Similar studies have reported a positive maternal attitude to immunization (Omotara et al., 2012; Hu et al., 2017; Vezzosi et al., 2017). Optimal vaccination programmes against chickenpox 
are effective in mitigating the disease burden, chickenpox-related hospitalization rate, morbidity, and mortality (Shapiro et al., 2011; García-Cenoz et al., 2013; Baxter et al., 2014; Amodio et al., 2015).

It was observed in this study that a high knowledge of chickenpox infection and vaccination will possibly improve the positive attitude and acceptability of chickenpox vaccination among mothers. A crosssectional survey carried out in Naples, Italy to examine the knowledge, the attitudes, and the behavior regarding the varicella infection and its vaccination among parents, revealed that a sufficient level of knowledge about the varicella vaccination was a significant predicting factor for vaccination acceptance (Vezzosi et al., 2017).

Despite the fact that chickenpox infection has relatively low morbidity and mortality rates in most settings, it still causes substantial burden on healthcare systems and the society at large (Heininger and Seward, 2006; Lozano et al., 2012; Hussey et al., 2017). The health benefits of immunization and vaccination cannot be over-emphasized as it constitutes a cost effective strategy to reduce both the morbidity and mortality associated with infectious diseases (Ophori et al., 2014). Quite a robust immunization programme has been initiated across the Nigerian healthcare system, however, there is need for the government to address the numerous drawbacks facing the success of the programme (Ophori et al., 2014; Oku et al., 2017; Akwataghibe et al., 2019), in order to improve the attitude and acceptance of immunization by its citizenry.

Conclusion: The current study indicated high level of knowledge and positive attitude towards chickenpox vaccination among child-bearing women of Abraka community of Delta State, Nigeria. It is essential to encourage pregnant women and mothers attending antenatal care to immunize their children against vaccine-preventable diseases (VPDs), as it would ensure a better attitude toward chickenpox vaccination.

\section{REFERENCES}

Akwataghibe, NN; Ogunsola, EA; Broerse, JEW; Popoola, OA; Agbo, AI; Dieleman, MA (2019). Exploring Factors Influencing Immunization Utilization in Nigeria - A Mixed Methods Study. Front. Public Health. 7: 392.

Amodio, E; Tramuto, F; Cracchiolo, M; Sciuto, V; De Donno, A; Guido, M; Rota, MC; Gabutti, G; Vitale, F (2015). The impact of ten years of infant universal Varicella vaccination in Sicily, Italy
(2003-2012). Hum. Vaccin. Immunother. 11(1): 236-9.

Baxter, R; Tran, TN; Ray, P; Lewis, E; Fireman, B; Black, S; Shinefield, HR; Coplan, PM; Saddier, P (2014). Impact of vaccination on the epidemiology of varicella: 1995-2009. Pediatrics. 134(1): 24-30.

Bonanni, P; Gershon, A; Gershon, M; Kulcsár, A; Papaevangelou, V; Rentier, B; Sadzot-Delvaux, C; Usonis, V; Vesikari, T; Weil-Olivier, C; de Winter, P; Wutzler, P (2013). Primary versus secondary failure after varicella vaccination: implications for interval between 2 doses. Pediatr. Infect. Dis. J. 32: e305-13

Center for Disease Control and Prevention (CDC) (2016). Vaccines and preventable diseases: Chickenpox/Varicella Vaccination. USA. Available

on: https:/www.cdc.gov/vaccines/vpd/varicella/inde x.html (accessed 18 May 2020).

Coniglio, MA; Platania, M; Privitera, D; Giammanco, G; Pignato, S (2011). Parents' attitudes and behaviours towards recommended vaccinations in Sicily, Italy. BMC Public Health. 11: 305.

D'Alessandro, A; Napolitano, F; D'Ambrosio, A; Angelillo, IF (2018). Vaccination knowledge and acceptability among pregnant women in Italy. Hum. Vaccin. Immunother. 14(7): 1573-1579.

García-Cenoz, M; Castilla, J; Chamorro, J; MartínezBaz, I; Martínez-Artola, V; Irisarri, F; Arriazu, M; Ezpeleta, C; Barricarte, A (2013). Impact of universal two-dose vaccination on varicella epidemiology in Navarre, Spain, 2006 to 2012. Euro. Surveill. 18(32): 20552.

Gershon, AA; Takahashi, M; Seward, JF (2013). Varicella vaccine. In: Plotkin SA, Orenstein WA, Offit PA (eds) Vaccines, 6th ed. Elsevier/ Saunders, Edinburgh, p.836-869.

Heininger, U; Seward, JF (2006). Varicella. Lancet. 368(9544): 1365-1376.

Hu, Y; Chen, Y; Wang, Y; Liang, H (2017). Knowledge, Attitude and Practice of Pregnant Women towards Varicella and Their Children's Varicella Vaccination: Evidence from Three Distrcits in Zhejiang Province, China. Int. J. Environ. Res. Public Health. 14(10): 1110. 
Hussey, H; Abdullahi, L; Collins, J; Muloiwa, R; Hussey, G; Kagina, B (2017). Varicella zoster virus-associated morbidity and mortality in Africa - a systematic review. BMC Infect. Dis. 17(1): 717.

Kreth, HW; Lee, BW; Kosuwon, P; Salazar, J; Gloriani-Barzaga, N; Bock, HL; Meurice, F (2008). Sixteen years of global experience with the first refrigerator-stable varicella vaccine (Varilrix). BioDrugs. 22(6): 387-402.

Kurugol, Z; Halicioglu, O; Koc, F; Koturoglu, G; Aksit, S (2011). Varicella rates among unvaccinated and one-dose vaccinated healthy children in Izmir, Turkey. Int. J. Infect. Dis. 15(7): e475-80.

Leung, J; Harpaz, R (2016). Impact of the maturing varicella vaccination program on varicella and related outcomes in the United States: 19942012. J. Pediatric Infect. Dis. Soc. 5: 395-402.

Lozano, R; et al (2012). Global and regional mortality from 235 causes of death for 20 age groups in 1990 and 2010: a systematic analysis for the Global Burden of Disease Study 2010. Lancet. 380: 2095-2128.

Ma, SJ; Li, X; Xiong, YQ; Yao, AL; Chen, Q (2015). Combination Measles-Mumps-Rubella-Varicella Vaccine in Healthy Children: A Systematic Review and Meta-analysis of Immunogenicity and Safety. Medicine (Baltimore). 94(44): e1721.

Marin, M; Guris, D; Chaves, SS; Schmid, S; Seward, JF (2007). Prevention of varicella: recommendations of the Advisory Committee on Immunization Practices (ACIP). MMWR Recomm. Rep. 56: 1-40.

Njidda, UM; Kever, RT; Lola, N; Dathini, H; Mshelia, A (2017). Assessment of parents' knowledge towards the benefits of child immunization in Maiduguri, Borno State, Nigeria. Nurse Care Open Access J. 3(2): 226-239.

Oku, A; Oyo-Ita, A; Glenton, C; Fretheim, A; Eteng, G; Ames, H; Muloliwa, A; Kaufman, J; Hill, S; Cliff, J; Cartier, Y; Bosch-Capblanch, X; Rada, G; Lewin, S (2017). Factors affecting the implementation of childhood vaccination communication strategies in Nigeria: a qualitative study. BMC Public Health. 17(1): 200
Omotara, BA; Okujagu, TF; Etatuvie, SO; Beida, O; Gbodossou, E (2012). Assessment of Knowledge, Attitude and Practice of Stakeholders Towards Immunization in Borno State, Nigeria: A Qualitative Approach. J. Community Med. Health Educ. 2: 181

Ophori, EA; Tula, MY; Azih, AV; Okojie, R; Ikpo, PE (2014). Current trends of immunization in Nigeria: prospect and challenges. Trop. Med. Health. 42(2): 67-75

Shapiro, ED; Vazquez, M; Esposito, D; Holabird, N; Steinberg, SP; Dziura, J; LaRussa, PS; Gershon, AA (2011). Effectiveness of 2 doses of varicella vaccine in children. J. Infect. Dis. 203(3): 312-5

Siedler, A; Dettmann, M (2014). Hospitalization with varicella and shingles before and after introduction of childhood varicella vaccination in Germany. Hum. Vaccin. Immunother. 10: 35943600

Streng, A; Grote, V; Carr, D; Hagemann, C; Liese, JG (2013). Varicella routine vaccination and the effects on varicella epidemiology - results from the Bavarian Varicella Surveillance Project (BaVariPro), 2006-2011. BMC Infect. Dis. 13: 303

Tafuri, S; Martinelli, D; De Palma, M; Germinario, C; Prato, R (2010). Report of varicella outbreak in a low vaccination coverage group of otherwise healthy children in Italy: the role of breakthrough and the need of a second dose of vaccine. Vaccine. 28(6): 1594-7

Trim, K; Nagji, N; Elit, L; Roy, K (2012). Parental Knowledge, Attitudes, and Behaviours towards Human Papillomavirus Vaccination for Their Children: A Systematic Review from 2001 to 2011. Obstet. Gynecol. Int. 2012: 921236

Vezzosi, L; Santagati, G; Angelillo, IF (2017). Knowledge, attitudes, and behaviors of parents towards varicella and its vaccination. BMC Infect. Dis. 17: 172

World Health Organization - WHO (2014). Varicella and herpes Zoster vaccines. WHO position paper, June 2014. Wkly. Epidemiol. Rec. 89: 265-287

Wutzler, P; Bonanni, P; Burgess, M; Gershon, A; Sáfadi, MA; Casabona, G (2017). Varicella vaccination - the global experience. Expert Rev. Vaccines. 16(8): 833-843. 